University of Nebraska - Lincoln

DigitalCommons@University of Nebraska - Lincoln

1993

\title{
Impacts, Tillites, and the Breakup of Gondwanaland
}

Verne R. Oberbeck

NASA Ames Research Center

John R. Marshall

NASA Ames Research Center

Hans Aggarwal

NASA Ames Research Center

Follow this and additional works at: https://digitalcommons.unl.edu/nasapub

Part of the Physical Sciences and Mathematics Commons

Oberbeck, Verne R.; Marshall, John R.; and Aggarwal, Hans, "Impacts, Tillites, and the Breakup of Gondwanaland" (1993). NASA Publications. 74.

https://digitalcommons.unl.edu/nasapub/74

This Article is brought to you for free and open access by the National Aeronautics and Space Administration at DigitalCommons@University of Nebraska - Lincoln. It has been accepted for inclusion in NASA Publications by an authorized administrator of DigitalCommons@University of Nebraska - Lincoln. 


\title{
ART I CLES \\ Impacts, Tillites, and the Breakup of Gondwanaland ${ }^{1}$
}

\author{
Verne R. Oberbeck, John R. Marshall, and Hans Aggarwal ${ }^{2}$ \\ NASA Ames Research Center, Moffett Field CA 94035, USA
}

\begin{abstract}
A B S T R A C T
Mathematical analysis demonstrates that substantial impact crater deposits should have been produced during the last 2 Gy of Earth's history. Textures of impact deposits are shown to resemble textures of tillites and diamictites of Precambrian and younger ages. The calculated thickness distribution for impact crater deposits produced during $2 \mathrm{~Gy}$ is similar to that of tillites and diamictites $\leq 2 \mathrm{Ga}$. We suggest, therefore, that some tillites/diamictites could be of impact origin. Extensive tillite/diamictite deposits predated continental flood basalts on the interior of Gondwanaland. Significantly, other investigators have already associated impact cratering with flood basalt volcanism and continental rifting. Thus, it is proposed that the breakup of Gondwanaland could have been initiated by crustal fracturing from impacts.
\end{abstract}

\section{Introduction}

Planetesimal impacts played an important role in Earth's history (Chamberlin 1920), the growth of the planets (Safronov and Zvjagina 1969; Safronov 1972), the origin of Earth's moon (Hartmann and Davis 1975), and in forming the topographic dichotomy on Mars (Wilhelms and Squyres 1984). Comet and asteroid impacts produced major formations on the surface of the moon; Short and Forman 1972 used the observed population of lunar impact craters to determine that impacts produced an average megaregolith layer $\leq 2 \mathrm{~km}$ thick. Hartmann 1980 calculated that a much thicker megaregolith was produced very early in the moon's history from craters no longer visible. Some of the major periods of lunar geologic history were defined by the formation of large craters and basins. Many of the rock stratigraphic units within the time systems are the deposits of large craters and basins (Wilhelms 1987; Oberbeck 1975).

Because the cratering rate on Earth was higher than that on the moon (Maher and Stevenson 1988|, even more extensive impact deposits must have formed here. Impacts could even have played a dominant role in crustal evolution. Frey 1980 and Grieve 1980 argued that the formation of large impact basins played a key role in the formation of proto-continents before $3.9 \mathrm{Ga}$ by producing a to-

\footnotetext{
${ }^{1}$ Manuscript received March 31, 1992; accepted August 28, 1992.

${ }^{2}$ Eloret Institute, Sunnyvale, CA 94087.
}

pographic dichotomy of 3-4 $\mathrm{km}$, massive volcanism, insulating ejecta deposits, subsidence, and reworking of volcanics leading to stable shield areas. This occurred in the first billion years of Earth's history when the impact rate was highest. Although the existence of terrestrial cratering is well documented after $3.9 \mathrm{Ga}$, not much attention has been given to crater deposits that may have survived in the rock record nor to the implications of the existence of such deposits. In this paper, we present the first comprehensive analysis of the thickness distribution of expected crater deposits on Earth in the past 2 billion years (Gy), when the cratering rate was constant, and after which most of the now surviving sedimentary rocks were formed. Because our results suggest that extensive crater deposits should have been produced, we then consider the nature of impact deposits and we compare them to tillites and diamictites heretofore thought to be of glacial origin. We then consider the possibility that many tillites are of impact origin and explore the implications of this idea for the generation of continental flood basalts and the breakup of Gondwanaland.

\section{Production of Impact Crater Ejecta Deposits during Geologic History}

To assess the extent of sedimentary deposits produced by impact, we calculated the fraction of the

[The Journal of Geology, 1993, volume 101, p. 1-19] No copyright claimed for this article. It remains in the public domain. 0022-1376-001\$1.00 
Earth's surface covered by crater ejecta during the last 2 Gy. Grieve and Dence (1979) tabulated all identified impact structures for the Phanerozoic by counting craters on the North American and East European cratons and estimated the rate of formation of terrestrial craters. We averaged their crater production rates (listed in their table 3) for craters $\geq 20 \mathrm{~km}$ and obtained a lower bound cratering rate of $2 \times 10^{-15} \mathrm{~km}^{-2} \mathrm{yr}^{-1}$ which is appropriate for at least the last $2 \mathrm{~Gy}$. Crater production functions obtained in the Basaltic Volcanism Study Project (1981), found that the number of craters produced larger than $D$ in kilometers was proportional to the -1.8 power of $D$ and cratering rate was constant after 3 billion years ago $(\mathrm{Ga})$. This production function has been adopted for terrestrial crater production by Maher and Stevenson (1988) and Oberbeck and Fogleman $(1989,1990)$. Thus, from the conservative estimate of the production of craters $>20$ $\mathrm{km}$ (Grieve and Dence 1979) and this functional relationship, we derive the general expression for production of the number of craters per $\mathrm{km}^{2}$ per $\mathrm{yr}$, $N$, larger than any observed diameter, $D$ (apparent diameter), after $2 \mathrm{~Gy}$ ago:

$$
N(D)\left[\mathrm{km}^{2} \cdot \mathrm{yr}\right]^{-1}=k D[\mathrm{~km}]^{-1.8}
$$

where $k=4.4 \times 10^{-13}$. This rate equation is supported by astronomical observations of present Earth-crossing asteroids and comets. For example, Shoemaker (1983) made astronomical observations of such asteroids and comets and converted the results to equivalent cratering rates that agree within the error bars with the rates determined from Grieve and Dence (1979) for the past 600 m.y.

From equation (1), and the surface area of Earth, the expected number of impact craters that should have formed over a 2 Gy period is: three $>750 \mathrm{~km}$, six $>500 \mathrm{~km}, 110>100 \mathrm{~km}, 2003>20 \mathrm{~km}, 6974$ $>10 \mathrm{~km}$, and $24,283>5 \mathrm{~km}$. Although crater numbers alone suggest that abundant ejecta deposits should exist in the geologic record, it is possible to determine the percentage of the area of the Earth that would be covered by ejecta of thickness $\geq$ a given thickness over the last two Gy.

Although Oberbeck (1975) and Oberbeck et al. (1975) have shown that crater deposits on the moon and Earth also include debris ejected from pre-existing rocks during emplacement of primary crater ejecta, we consider only the primary crater ejecta here for a conservative estimate of the amount of debris. We now derive a relationship for the fractional coverage of the Earth's surface, $A_{f}$, by ejecta blankets with thickness $\geq t(\mathrm{~km})$ produced by craters between $D_{\min }$ and $D_{\max }$ in $2 \mathrm{~Gy}$.

The thickness, $t$, of ejecta, surrounding an im- pact crater formed on Earth is given by McGetchin et al. (1973) and Seebaugh (1977) as:

$$
t(\mathrm{~km})=k_{0}\left(\frac{r(\mathrm{~km})}{R(\mathrm{~km})}\right)^{-\alpha}
$$

where $k_{0}$ is a constant determined by total crater ejecta, $\alpha$ is the ejecta blanket thickness decay constant $=3.5, r$ is the distance from the crater center, at which ejecta thickness is $t$ and $R$ is crater radius. The volume of the ejecta is then given by:

$$
\text { Ejecta Volume }\left(\mathrm{km}^{3}\right)=2 \pi \int_{R}^{10 R} r t d r=\frac{2 \pi k_{0} F}{\alpha-2} R^{2}
$$

where,

$$
F=1-\frac{1}{10^{\alpha-2}}
$$

and ejecta thickness is integrated from $R$ to $10 R$, within which practically all of the ejecta is deposited. Craters are assumed to be spherical segments, so crater volume is given by:

$$
\text { Crater Volume }\left(\mathrm{km}^{3}\right)=\pi / 6 R^{3} C\left(3+C^{2}\right)
$$

where $R$ is apparent crater radius, $C$ is the ratio of the crater depth to crater radius. Setting ejecta volume equal to crater volume and simplifying gives:

$$
\begin{gathered}
2 \pi \frac{k_{0} F}{\alpha-2} R^{2}=\frac{\pi}{6} R^{3} C\left(3+C^{2}\right) \\
k_{0}=\frac{\alpha-2}{12} \frac{R C\left(3+C^{2}\right)}{F}
\end{gathered}
$$

Substituting this value of $k_{0}$ in equation (2) gives the change in the ejecta thickness, $t$, with distance $r$ from a crater of radius $R$ :

$$
t(\mathrm{~km})=\frac{\alpha-2}{12} \frac{C\left(3+C^{2}\right)}{F} \frac{R^{\alpha+1}}{r^{\alpha}}
$$

where $r$ and $R$ are in kilometers. This may be expressed as:

$$
r^{\alpha}=\frac{\alpha-2}{12} \frac{C\left(3+C^{2}\right)}{F t} R^{\alpha+1}
$$

or

$$
r=\left[\frac{\alpha-2}{12} \frac{C\left(3+C^{2}\right)}{F t} R^{\alpha+1}\right]^{1 / \alpha}
$$


Note that within the area of an ejecta blanket at radius $r$ from a crater of radius $R$, where the ejecta thickness is $t$, the ejecta thickness is $\geq t$ because ejecta thickness decreases with distance from the crater rim (see equation 2). The incremental area of ejecta $\geq t$ (per unit surface area) from craters of diameter $D$ is the product of $n(D)$ and the area around the crater within which the ejecta is $\geq t$. Therefore, the fractional coverage per year of the surface $(A)$ of ejecta of thickness $\geq t$ by all craters is given by:

$$
\begin{gathered}
A\left(\frac{\mathrm{km}^{2}}{\text { Surface area of earth }\left(\mathrm{km}^{2}\right) \cdot \mathrm{yr}}\right) \\
\quad=\int_{D_{\min }}^{D_{\max }} n(D) \pi\left(r^{2}-R^{2}\right) d D
\end{gathered}
$$

where $r$ is given by equation (10), $R=D / 2, D_{\max }$ and $D_{\text {min }}$ are the maximum and minimum diameters of the craters, $n(D)$ is the incremental crater number density at diameter $D$, per unit crater diameter, per $\mathrm{km}^{2}$ of the surface, per $\mathrm{yr}$, given by Maher and Stevenson (1988) by a function of form: $n(D) /\left[\mathrm{km}^{3} \cdot \mathrm{yr}\right]=d N / d D=1.8 \mathrm{k} f(\tau) / D^{2.8} \cdot \mathrm{k}$ is a constant determined here from the conservative estimate of the terrestrial cratering history of the last several billion years, given in equation (1) as $4.4 \times 10^{-13}, f(\tau)=1$ during the last $2 \mathrm{~Gy}$ (Maher and Stevenson 1988). The integral of the incremental crater number density at $D$ gives Equation (1).

Substituting $n(D)$, defined above in the text and $r$ from equation 10 , and replacing $R$ by $D / 2$ in equation 11 and simplifying gives:

$$
\begin{gathered}
A=\frac{1.8 \pi}{4} k f(\tau) \int_{D_{\min }}^{D_{\max }} \\
\times\left[\left\{\frac{\alpha-2}{24} \frac{C\left(3+C^{2}\right)}{F t}\right\}^{2 / \alpha} D^{2-0.8 \alpha / \alpha}-D^{-0.8}\right] d D
\end{gathered}
$$

or, after integration:

$$
\begin{aligned}
& A=\frac{1.8 \pi}{4} k f(\tau)\left[\left\{\frac{\alpha-2}{24} \frac{C\left(3+C^{2}\right)}{\mathrm{Ft}}\right\}^{2 / \alpha}\right. \\
& \times \frac{\alpha}{2+0.2 \alpha}\left(D_{\max }^{(2+0.2 \alpha) / \alpha}-D_{\min }^{(2+0.2 \alpha) / \alpha}\right) \\
& \left.-5\left(D_{\max }^{0.2}-D_{\min }^{0.2}\right)\right]
\end{aligned}
$$

Substituting $k$ and multiplying by $2 \times 10^{9}$ yr to express $A$ in terms of $A_{f}$, the fraction of Earth's surface covered by ejecta of thickness, $\geq t$ in the past Gy of earth history, we have:

$$
\begin{aligned}
& A_{f}=12.44 \times 10^{-4} f(\tau)\left[\left\{\frac{\alpha-2}{24} \frac{C\left(3+C^{2}\right)}{F t}\right\}^{2 / \alpha}\right. \\
& \left.\times \frac{\alpha}{2+0.2 \alpha}\left(D_{\max }^{(2+0.2 \alpha) / \alpha}-D_{\min }^{(2+0.2 \alpha) / \alpha}\right)-5\left(D_{\max }^{0.2}-D_{\min }^{0.2}\right)\right]
\end{aligned}
$$

Let us calculate the fractional area of Earth covered by ejecta with thickness $\geq t$ produced in a 2 Gy period of time for all possible values of $t$. We must first obtain the largest expected crater, $D_{\max }$, in 2 Gy because it is needed for eq. (14), and it is necessary to know the upper limit of $t$ at which equation (14) may be evaluated. The largest value of $t$ is the rim ejecta thickness for the largest crater, $D_{\max }$. We now use the rate of formation of craters on Earth and the Poisson probability distribution to estimate the maximum size crater that should be expected during the last $2 \mathrm{~Gy}$.

Using the cratering rate equation for craters equal or larger than a given diameter given by equation (1), on average, about three craters $\geq 750$ $\mathrm{km}$ should have been formed in $2 \mathrm{~Gy}$ time intervals on an Earth-size body if it were repeatedly subjected to an impactor flux identical to Earth's impact flux. This does not ensure that craters as large as $750 \mathrm{~km}$ actually formed on Earth in the last 2 Gy. The probability of $n$ impact craters of this diameter, given that the expected number, $N_{T} P=$ 3 is given by the Poisson probability distribution:

$$
P(n)=\left(N_{T} P\right)^{n} / n ! e^{-N_{T} P}
$$

where $N_{T} P=3 . N_{T}$ is the total of all craters $>5$ $\mathrm{km}$ produced in $\mathrm{Gy}$ and $P$ is the proportion of craters $>750 \mathrm{~km}$. This probability distribution gives the probability of occurrence of rare events (craters $\geq 750 \mathrm{~km}$ ) when the proportion of such events of the total events (all other crater sizes) is very small (Snedecor and Cochran 1976).

Using equation (15) for discrete values of $n$, we find that the probability is 0.95 that $n \geq 1$ crater $>750 \mathrm{~km}$ should have formed on Earth in the last 2 Gy (there is $5 \%$ probability that 0 craters this large actually formed). Repeating the calculation for $500 \mathrm{~km}$ craters, we find that the probability for formation of one or more craters $\geq 500 \mathrm{~km}$ is 0.9975 . The probability for 0 craters $\geq 500 \mathrm{~km}$ approaches 0 . Therefore, we can be certain that craters as large as $500 \mathrm{~km}$ formed in the last $2 \mathrm{~Gy}$. $D_{\max }$ in equation (14) can be safely taken as 500 $\mathrm{km}$ and $\mathrm{D}_{\min }=5 \mathrm{~km}$. We next need a value of $C$ 
for equation (14) and it, together with $R=D_{\max } / 2$ in equation (8) determines the largest value of $t$ for which equation (14) should be evaluated.

Head et al. (1975) determined $C=0.02-0.4$ for large lunar impact craters. The smallest value was obtained from depths of craters and basins filled by a variety of post-impact processes. The largest is the ratio for fresh small craters; some authors also believe it characterizes large fresh craters (Melosh 1982; Orphal 1979). A lower bound estimate of area covered by ejecta $\geq t$ results from use of $C=$ 0.02 in equation (14). This ejecta rim height is near the lower bound rim thickness estimated for an impact crater of this size on the moon as found by Head et al. (1975). With $C=0.02$ in equation (14), the computed fraction of the Earth's surface covered by ejecta with thickness $\geq t$ in 2 Gy is calculated and given in figure 1 . We evaluate this relationship up to $1.94 \mathrm{~km}$, the maximum thickness of ejecta for a $500 \mathrm{~km}$ crater with this depth-radius ratio (equation 8). Calculations suggest that at least $10 \%$ of the Earth's surface could have been covered by ejecta deposits $\geq 10 \mathrm{~m}$ in $2 \mathrm{~Gy}$. About $2 \%$ of the Earth's surface would have been covered with ejecta $\geq 200 \mathrm{~m}$ in thickness. Maximum thickness is $1.94 \mathrm{~km}$. We obtained an alternate estimate that agrees with these results by using our value of $\alpha=3.5$ and the empirical relationship for ejecta thickness around impact craters given by McGetchin et al. (1973).

As noted earlier, results of Orphal (1979) and Melosh (1982) suggest that the ratio of crater depth to crater radius of a fresh crater could be as large as 0.4. Using equation (14) and $C=0.4$, in the last $2 \mathrm{~Gy}$, craters covered $61 \%$ of the Earth with ejecta $\geq 10 \mathrm{~m}, 10 \%$ with ejecta $\geq 200 \mathrm{~m}$ thickness, and $5.5 \%$ with ejecta $\geq 500 \mathrm{~m}$. These are upper bound

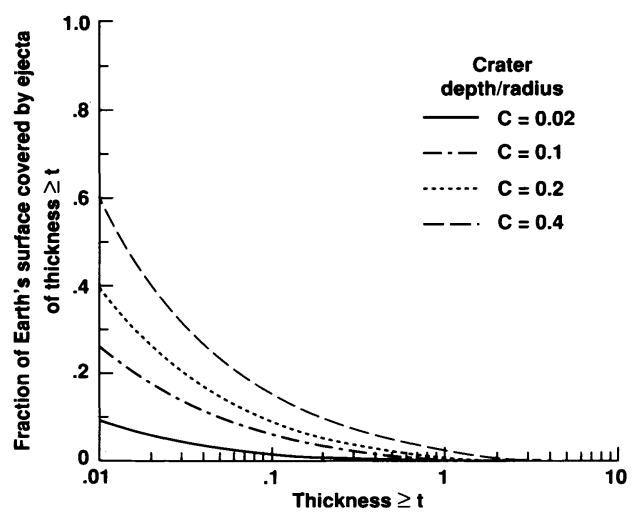

Figure 1. Calculated fraction of Earth's surface covered by ejecta of thickness $\geq t(\mathrm{~km})$ for different assumed values of crater depth-radius ratios, $C$. estimates of the area of Earth's surface covered by ejecta because they use $C=0.4$ and observed crater volume as an estimate of ejecta volume.

Both methods of calculation suggest that substantial crater deposits should have been produced during geologic history. Deposits of small craters formed on land could have been eroded. However, at many times in geologic history vast regions of the continents were covered by shallow seas which would hardly reduce the amount of material ejected from a $5 \mathrm{~km}$ crater compared to that ejected from such a crater on land. Craters $>5 \mathrm{~km}$ formed on the continental shelf or shallow inland seas would produce slurry waves several hundred meters high. Wave action would spread the deposits further away from the impact site than on land and material backwashed from the continents would result in thicker deposits than those of terrestrial craters. Deposits of even small craters that formed in shallow water should have been preserved beneath later sediments.

\section{Deposits of Impact Craters Formed on Land}

Although the deposits of many of the ancient impact craters on land are often eroded, the ejecta of the Ries crater, Germany survives relatively intact. Horz et al. (1977) drilled deposits surrounding this $26 \mathrm{~km}$ crater that formed on land and found that the cores contained mixtures of monomict or polymict clasts, and megaclasts in a matrix of finegrained material. Clasts were defined as those between $1 \mathrm{~cm}$ and $1 \mathrm{~m}$ in size; these had random orientation within the fine-grained matrix. Megaclasts measured into the tens of meters occurred within the Ries crater ejecta (Bunte Breccia) which was itself as thick as $84 \mathrm{~m}$. The deposit contained predominantly crater ejecta in regions near the crater and predominantly local material (which had been torn up and incorporated with crater ejecta) at great distances. Dislodged blocks as large as 200 $\mathrm{m}$ were found. Contorted clast and matrix structures indicated a very energetic emplacement mechanism. The deposits are predominantly massive although, on occasion, clasts show preferred orientation, and there are rare lineations in the matrix. Figure 2 shows a quarry section of Bunte Breccia. Much of the ejecta is very fine-grained, but there is an unsorted chaotic mixture of clasts of various sizes in the fine-grained matrix.

Horz et al. $(1977,1983)$ found that Ries impact crater ejecta stripped local ground during emplacement to regions below the weathering zone. They described radial scouring and striations on preexisting Jurassic limestones where ejecta im- 


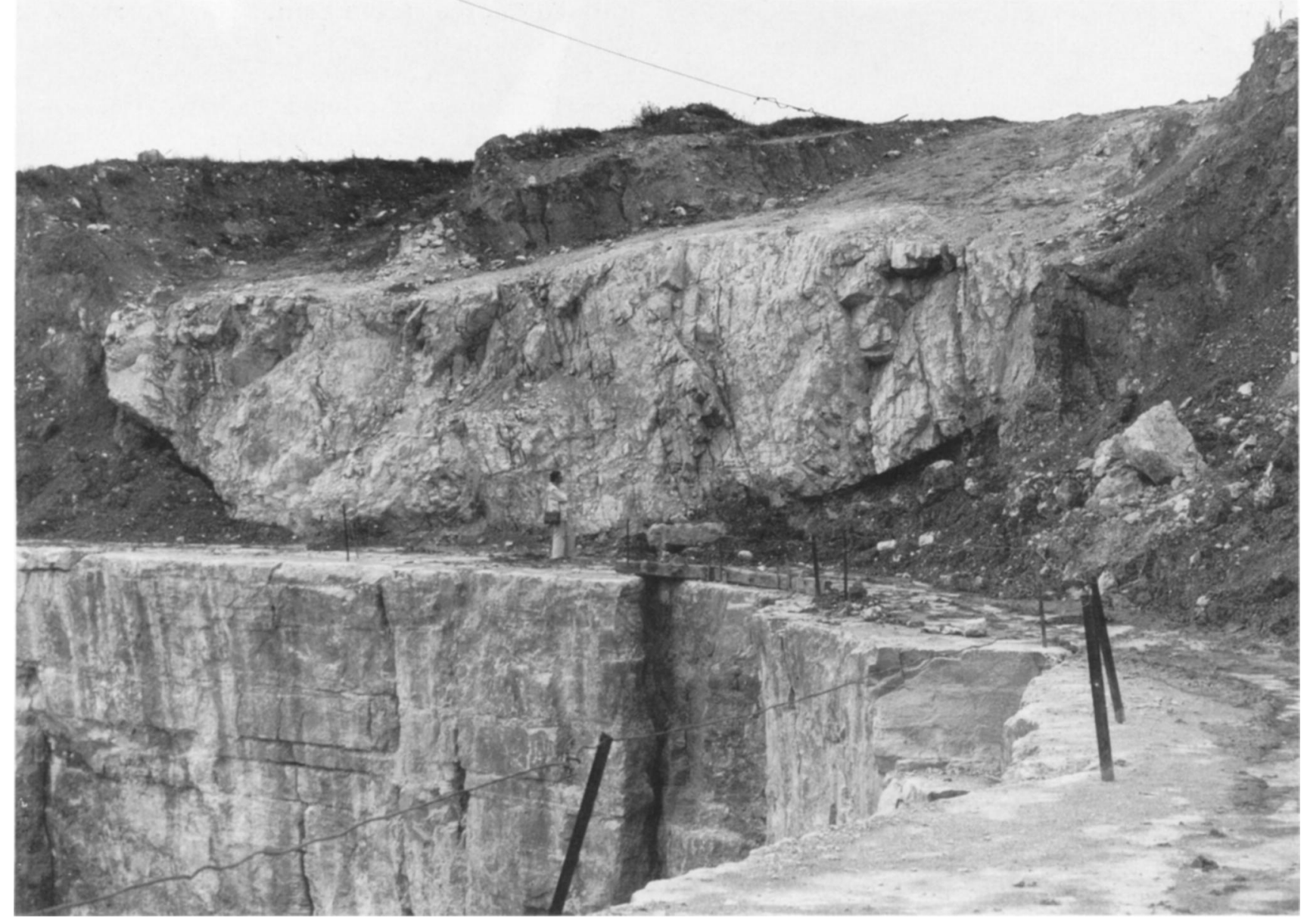

Figure 2. Ries impact crater ejecta deposit (Bunte Breccia) resting on pre-impact limestone surface. Note the clasts and megaclasts within the fine-grained matrix and the chaotic texture of the deposit.

pacted, eroded the ground, and moved along the surface. Pohl et al. (1977) described Bunte Breccia deposits as thick as $200 \mathrm{~m}$ in places where precrater depressions trapped the ground-hugging flow; in places they produced polished and striated surfaces.

Horz et al. (1977, 1983) explained the complex Bunte Breccia mixtures of crater ejecta and local ground using the ballistic erosion and sedimentation model of Oberbeck (1975). According to this model (figure 3), material is ejected from craters in ballistic trajectories. The first material ejected from nearest the impact point has the highest velocity; it is found at the top of an expanding conical ejecta curtain and it is deposited at the greatest distance. The lowest velocity material is ejected last from the crater from points near the final crater rim, and it is also deposited nearest the crater rim. For large craters, much of the ejecta impacts with high enough velocity that it excavates preexisting ground. Thus, at progressively greater distances from the crater rim, ever increasing amounts of local ground are torn up by the ejecta. Excavated material is added and mixed with the primary crater ejecta. This complex mixture of crater ejecta and local ground moves away from the impact site in a ground-hugging flow behind the ejecta curtain. It produces a chaotic mixture of clasts of rock in a fine-grained matrix resting on deformed, striated, and eroded substrates.

\section{Deposits of Impact Craters Formed in Water}

Deposits of even small impact craters should have survived in the rock record if they were produced in shallow inland continental seas or shelf areas. Throughout geologic history, much of the continental regions were flooded by shallow seas; these would not have substantially decreased the amount of ejecta from the sea floor even for craters as small as $5 \mathrm{~km}$. Such craters would have been over $1 \mathrm{~km}$ deep and the shallow water would only 


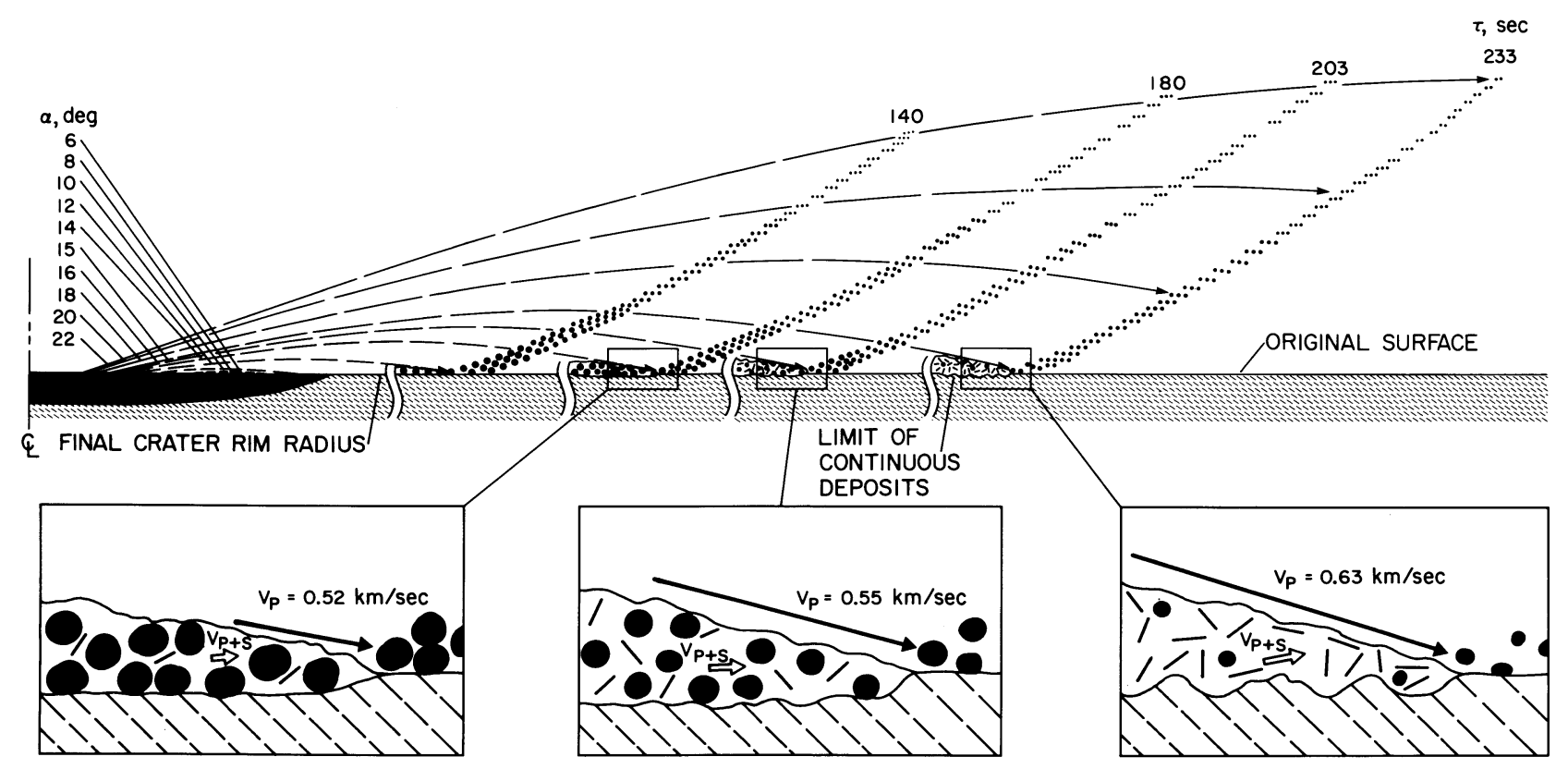

Figure 3. Schematic of calculated positions of ejecta curtain with respect to ejecta in ballistic trajectory for the lunar crater Copernicus, from Oberbeck (1975). Note that material from the crater is ejected in ballistic trajectories and material with the highest launch velocities is transported farthest. When ejecta strikes the ground, secondary cratering causes ejecta ground mixing, material moves in a ground hugging flow, and a chaotic mixture of clasts and fine grained matrix material is produced.

have been a small part of the ejecta. Material from the deep ocean floor would only have been ejected from craters $>15 \mathrm{~km}$.

It is largely due to the search for the impact crater that occurred at the end of the Cretaceous period that we can now anticipate the wide variety of lithologies of impact deposits formed in water. Smit and Romein (1985) describe deep sea cores spanning the $\mathrm{K} / \mathrm{T}$ boundary and show that in 15 cores world-wide, there is only a thin layer of microtectites (melted ejecta). Ahrens and O'Keefe (1983) performed a theoretical analysis that showed that a minimum threshold energy is required to erode deep ocean sediments and produce widespread turbidity deposits. Thus, only microtectites occur in most deep sea cores. However, a series of thicker ejecta and turbidity deposits along with altered microtectites exist closer to the $\mathrm{K} / \mathrm{T}$ impact. These and similar deposits indicate the nature of water-laid ejecta deposits. Florentin et al. (1991) described a deposit about $72 \mathrm{~cm}$ thick in Beloc, Haiti some 1100 miles from the suspected source crater Chicxulub on the north coast of $\mathrm{Yu}$ catan. From the top down, it consists of a thin clay layer, a laminated sandy marl containing small lenses of coarse clay spherules (altered microtectites), a white chalk lens, an upward-fining graded sandy marl, a coarse spherule-bearing marl lens, fine spherules in a sandy marl, and coarse spherulerich crater ejecta. These textures were interpreted to have formed from a complex series of events including deposition of crater materials followed by reworking from disruptive impact-generated tsunamis.

Bourgeois et al. (1988) described another K/T boundary turbidity deposit in Texas about $1 \mathrm{~m}$ thick (figure 4). Here, material exhibiting an iridium anomaly (diagnostic of extraterrestrial material) overlies a coarse-grained sandstone with large clasts of mudstone and reworked carbonate nodules with an erosional base with up to $70 \mathrm{~cm}$ of relief; the deposit grades upward to very finegrained sandstone. Slump structures and parallel and wave ripple laminations are found above the graded base of the deposit. The authors concluded that the deposit resulted from a 50 to $100 \mathrm{~m}$ high tsunami wave produced by impact of a bolide; the mudstones eroded by the wave existed in water about $75 \mathrm{~m}$ deep, and the sandstones were transported from inner shelf facies. Multiple sediment beds indicated that multiple waves could have been responsible. The graded sandstone was deposited in about one day, whereas the mudstone above it was deposited within a few weeks of the event. Slump structures were also produced when the impact caused instabilities in shelf sediments. Impact 


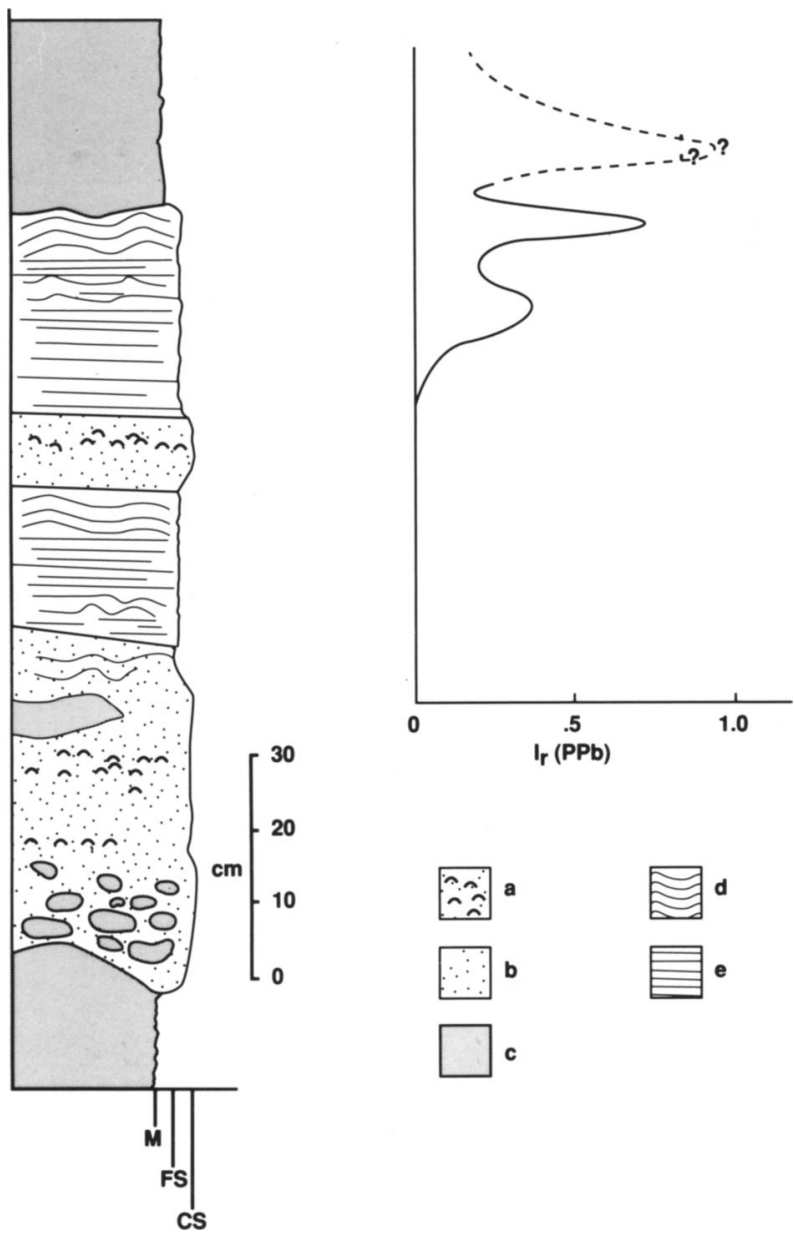

Figure 4. $\mathrm{K} / \mathrm{T}$ impact deposit near Brazos River, Texas, reproduced after the stratigraphic section diagram in Bourgeois et al. (1988). (a) Sand with shell debris; (b) Sand; (c) Mudstone; (d) Wave ripple laminated material; and $(e)$ Parallel laminated sediments.

of a $10 \mathrm{~km}$ bolide in the deep ocean as far away as $5000 \mathrm{~km}$, or a much smaller one nearby, could have produced the conditions required to explain this deposit.

Hildebrand (1991) suggested that the thickness of distal K/T ejecta deposits may be used with decay laws similar to equation $(8)$ to predict the thickness of proximal $100 \mathrm{~m}$ thick crater ejecta deposits (intercalated with pelagic sediments) about $100 \mathrm{~km}$ from Chicxulub. Vickery et al. (1992) have shown that the thickness of deposits at various distances from Chicxulub agree with those predicted by the McGetchin relationship that we used to obtain area thickness distributions for impact ejecta during the past 2 Gy. Alvarez et al. (1991) described a proximal incomplete $45 \mathrm{~m}$ thick section of pebbly mudstone overlain by $4 \mathrm{~m}$ of current-bedded sandstone containing glassy ejecta with upward fining grains covered by reworked calcareous oozes. Equation 8 and the results of Hildebrand (1991) suggest that even thicker undiscovered deposits should exist in regions even closer to the impact site. The textures of deposits closest to the crater can be deduced from water-lain ejecta occurring elsewhere at different times. For example, extensive 10-60 m Eocene marine beds of mixtites were described at the coastal plain of southeastern Virginia and attributed to impact by Poag et al. (1991). This bed consists of an upward-finding graded bed containing angular clast of pebbles and boulders up to $1 \mathrm{~m}$ in diameter within a glauconitic, clayey, sand matrix. The deposit occupies an area of $14,000 \mathrm{~km}^{2}$ and is equivalent stratigraphically to impact ejecta located elsewhere.

Dropstones also exist in water-lain impact ejecta. Gostin et al. (1986) report a 1575 Ma solitary layer of shattered volcanic rock fragments in the Adelaide Geosyncline, South Australia, that exhibited shock lamellae and shatter cones characteristic of impact ejecta. A distant source crater known as Lake Acraman has been located in the Gawler Range of Volcanics $300 \mathrm{~km}$ west of the Adelaide Geosyncline (Williams 1986). The ejecta deposit was traced over a distance of $260 \mathrm{~km}$ in $600 \mathrm{Ma}$ Precambrian marine shales. Fragments in this deposit, up to $30 \mathrm{~cm}$, formed classic dropstone structures when they fell in the ocean on preexisting marine sediments. Figure 5 is a sketch of the Gowler range sediment section adapted from the section portrayed in Gostin et al. (1986). Layer A is poorly sorted angular sand with blocks of shocked volcanic material up to $30 \mathrm{~cm}$ ejected from the impact crater to form dropstone structures in ocean-bottom sediments. Layer B is a thin green drape of sand that was put into suspension by the impact. Layer $C$ is a thin, graded layer of sandy impact debris that took longer to settle out. Layers D and $\mathrm{E}$ exhibit multiple grain sizes and crossbedding and were deposited at undetermined times after the impact by turbidity currents and storms. Textures of these types should be present in the sea areas in regions distant from rims of impact craters.

Water-Formed, Large Impact Crater Model. In figure 6, an impact is depicted in a shallow sea. Ahrens and O'Keefe (1983) concluded that a kmscale wave could have resulted from an impact in the ocean. McKinnon (1982) suggested that, because the shock-wave velocity in the crust exceeds that in water, material from the ocean floor would have been mixed with ocean water during crater formation. The cratering event should have ejected a mud slurry; material in the crater rim wave 


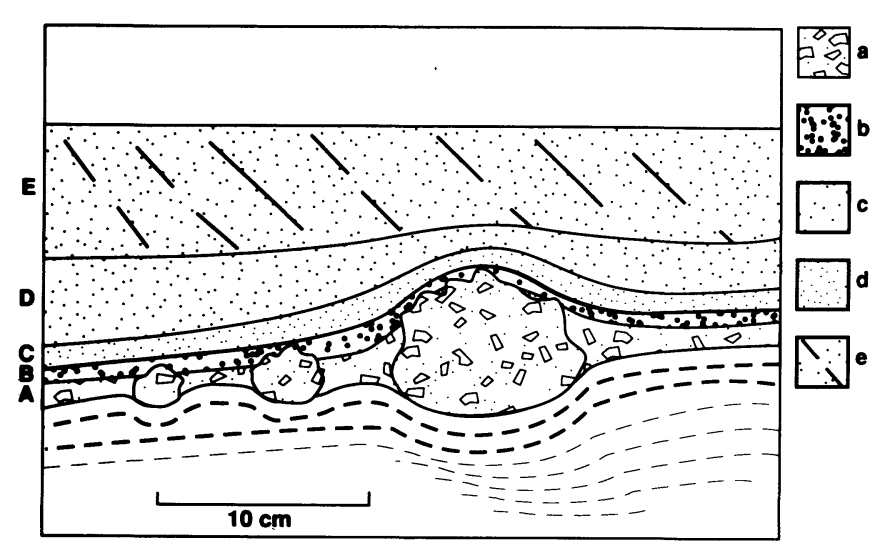

Figure 5. Section of a Precambrian crater ejecta blanket adapted from a stratigraphic section in Gostin et al. (1986). (a) Basal layer of poorly sorted angular sand and sparse blocks up to $30 \mathrm{~cm}$ of dacite to rhyolite produced from vertical fall of ballistic ejecta. (b) Thin green drape of sand resettled from sediments put into suspension by impact generated seismic waves. (c) Thin graded layer of sand fragments. Impact debris finer than in $a, b$ taking longer to settle. (d), $(e)$ Lenticular layers of sand up to $40 \mathrm{~cm}$ thick showing multiple grain size and in layer $e$ crossbedding deposited at undetermined time after impact by turbidity currents or storms.

would be a mixture of water and sediment. In $6_{1}$, during the formation of the transient crater, the raised crater rim is a "slurry" wave. Before collapse of the rim, the supersonic ballistic ejecta curtain spreads some distance from the impact site. Note that the ejecta from the curtain that settles through the water has been sorted both aerodynamically and hydrodynamically before coming to rest on the sea floor where graded beds result.

In figure $6_{2}$, collapse of the transient slurry rim gives rise to a tsunami that is sufficiently erosive at the sea bed to cause reworking of some of the ejecta deposits as well as sediments not overlain by ejecta. Collapse of the transient crater causes a central water spout to form from the inrushing sea; such water spouts have been confirmed by experiment (Engel 1961; Gault and Sonett 1982). Collapse of the water spout generates a second tsunami; several waves might be expected before the disturbance to the sea finally damps out.

In figure $6_{3,4,5}$ and 6 , the tsunamis are shown striking a proximal deltaic region that suffers massive disruption; large volumes of sediment slump down the foreset region, accompanied by numerous turbidity flows. Events in the deltaic/littoral zone are additionally complicated by the backwash of water and terrestrial sediments from the return flow of the tsunamis that swept inland.
Figure 7 depicts sedimentary sequences generated by the events in figure 6 . The dashed line is the original undisturbed surface level. Section (1) represents deep sea deposits (not depicted in figure 6). In distal regions, the impact is represented by dispersed dropstones $(d)$. The overlying calcareous horizons were produced by tsunamis that reworked and redistributed seafloor calcareous oozes. At very distal regions, only a very thin ( $\mathrm{cm}$-scale) layer of microtectites exists. In regions close to the impact (sections 2 and 3 ) crudely graded ejecta deposits have several upper water-sorted beds separated by unconformities. Lower layers have megaclasts (m). Uppermost layers are finely-laminated argillaceous materials ( $\mathrm{l}$ ) produced by turbidity currents that continue for many years after the impact as the slopes regain equilibrium. Section 4 depicts a chaotic mixture of ejecta, reworked sediments, massive slump deposits, and turbidity-current scour and fill. Section 5 is also a chaotic deposit produced from current reversals at the site lonshore tsunamis and off-shore backwash). In section 6 , the absence of water cushioning has allowed high-velocity ejecta to plough and brecciate the substrate beneath reworked blanket material.

At all locations, host rock is mixed with ejecta. At sites 2 and 3, sediment overburden weight was applied non-uniformly to the sediments, and ejecta was squeezed into host rocks. At site 4 , the mixing also results from incorporation of slumped substrate blocks (b). At site 5, mixing results from high-velocity penetration of ejecta into soft sediments that are insufficiently protected by the shallow water. At site 6, high-velocity impact into a more rigid substrate produces a more highly brecciated and splintered substrate $(i$; incorporated material).

Impact in water generates sedimentary facies that are (1) laterally and vertically extensive, (2) very complex, and (3) highly variable from one location to another. They contain clasts of rock in a fine-grained matrix. Clasts are largest at the base of the formations. These typically grade upward to fine-grained material that displays laminations reflecting turbidity flows. Dropstone features occur in water-lain impact deposits when large clasts of rock fall into the ocean and deform soft marine sediments. Deposits can contain both sorted and unsorted massive graded and layered beds, erratics, and cross-bedding. The type and character of such deposits depends upon their distance from the impact site. The thickest, most massive deposits with the largest clasts exist nearest the impact site. Further away, thinner deposits become more lineated and better sorted; they can contain reworked mate- 


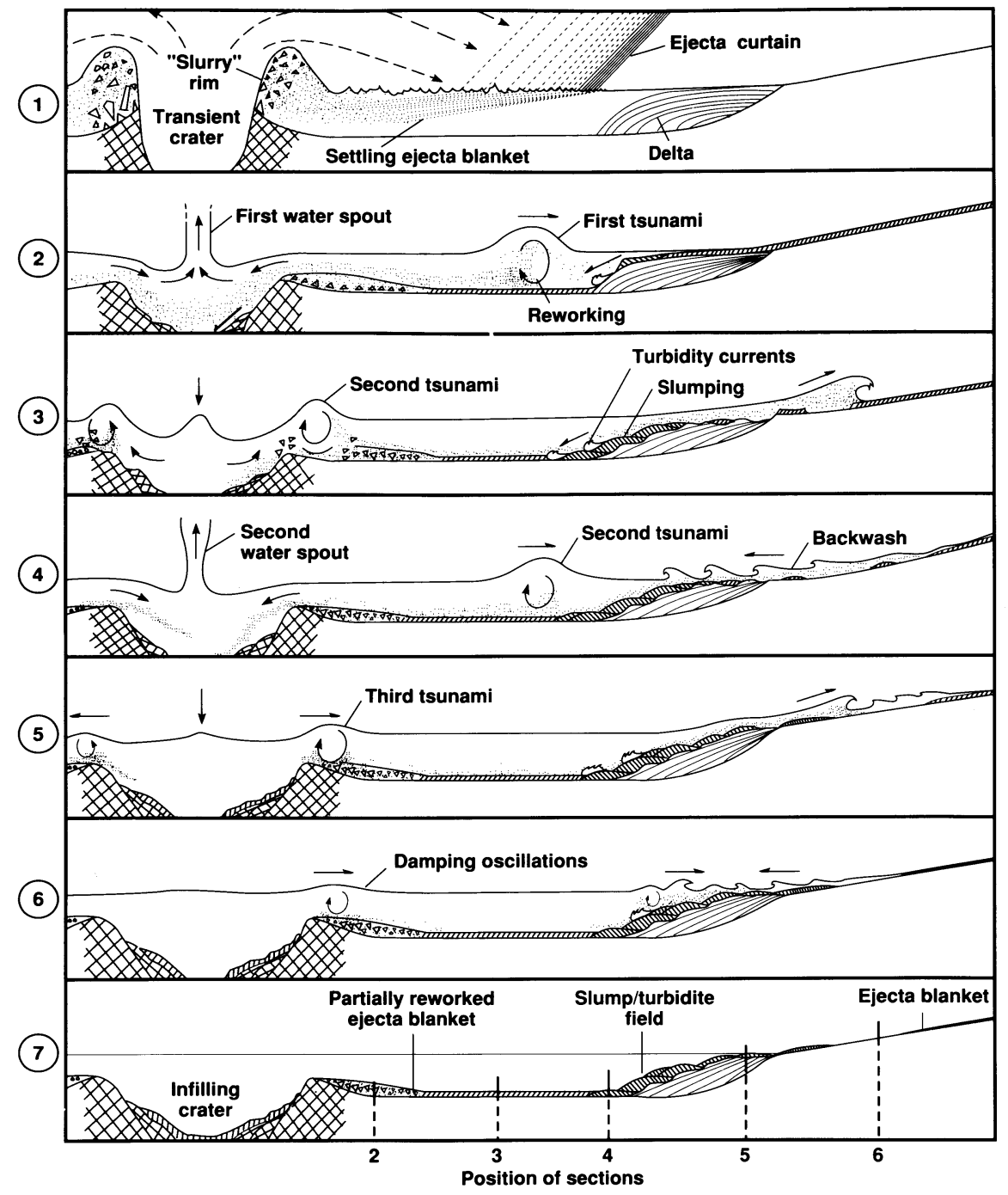

Figure 6. Hypothetical sequence of events produced by impact of a mantle-penetrating bolide striking a shallow sea. Sequence is described in text. Sequence 1 to 7 would occur over a period of several hours. Vertical scale is exaggerated. rial including calcareous deposits. At still greater distances, dropstones deform soft pre-existing marine beds. Microtectites are also found, produced from the cooling vapor cloud containing material that experienced the greatest shock heating.

\section{Description of Tillite and Diamictite Deposits}

Precambrian and younger tillites and diamictites have textural characteristics similar to those of impact crater deposits and predicted by our impact model. An excellent summary of tillites believed to be indurated glacial tills is given by Gravenor et al. (1984), who divided them into seven different lithologic classes. The first till-tillite class contains a polymodal size distribution of clasts, and the supporting fine-grained matrix can contain sheared lenses of silt, sand, and conglomerate. No lineations or other ordered structures exist. This type occurs in terrestrial environments and often creates grooved and striated deformations on the underlying formations. These deposits are interpreted as having been deposited directly at the base of a grounded glacier. An example is the Jequitai facies, Minas Gerais, Brazil, which contains clasts up to $25 \mathrm{~m}$ intermixed with fine-grained material (Gravenor and Monteiro 1983).

The second class is similar to the first but, additionally, it shows faint layers and laminations at the top of the formations and wisps of sand and contorted structures. These textures are interpreted to have been produced by melting at the base of active floating or partially floating ice as sediments were deposited from a slurry near the grounding line. An example is the Cacaratiba facies, gradational to the Jaquita facies just described. Other classic examples are in the Parana 

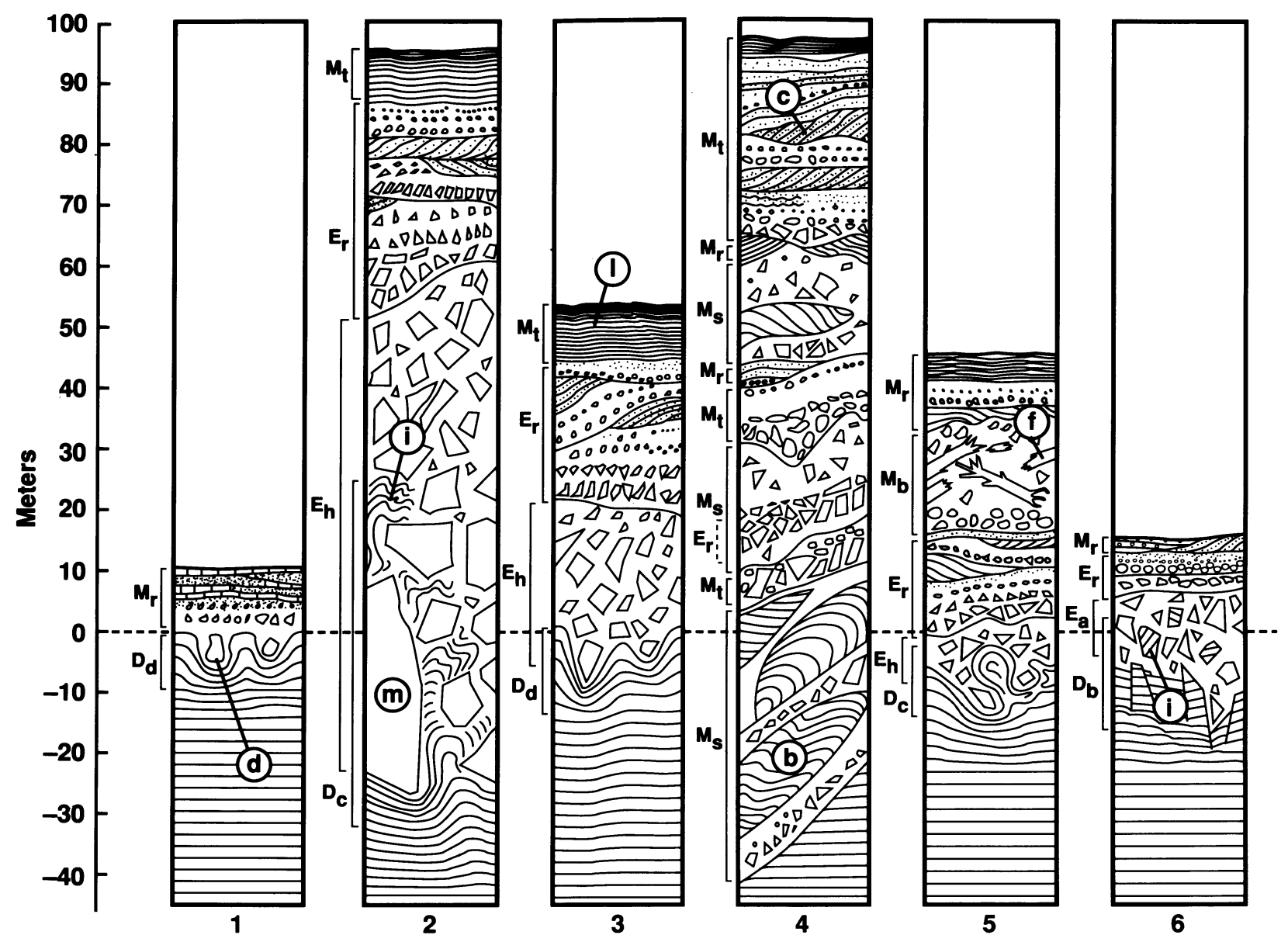

Figure 7. Sedimentary rock sequences resulting from impact in shallow sea. Sections correspond to locations in Figure 6 and are described in the text. Sediment types: $\mathrm{E}=$ ejecta material: $\mathrm{Eh}=$ water-deposited; Ea $=$ subaeriallydeposited; $\mathrm{Er}=$ reworked. $\mathrm{D}=$ disturbed substrate material: $\mathrm{Dd}=$ dropstone disturbance; Dc $=$ compressional disturbance; $\mathrm{Db}=$ brecciated. $\mathrm{M}=$ mobilized material: $\mathrm{Mt}=$ turbidity; $\mathrm{Ms}=$ slump; $\mathrm{Mb}=\mathrm{backwash}$; $\mathrm{Mr}=$ reworked. $\mathrm{d}=$ dropstone. $\mathrm{m}=$ megaclasts. $\mathrm{i}=$ injected host material. $\mathrm{l}=$ laminations. $\mathrm{b}=$ slump blocks. $\mathrm{c}=$ cross bedding. $\mathrm{f}=$ terrestrial flora deposits.

basin in South America and in the Karoo basin of South Africa.

The third type is a massive layered bed containing matrix-supported clasts that can grade to predominantly clast assemblages with a wide variation of lithology. Clasts can be oriented or random, and beds may be separated or superposed by rythmites, mudstones, or siltstones, and by slump structures. This type of tillite is interpreted as redistributed subaquatic glacial material, some of which can arise from slumping. They are believed to have resulted from debris flowing into paraglacial lakes or in shelf environments in the sea.

The fourth type of till-tillite is partially comprised of laminated sorted sediments of coarse sand, silt and clay, where laminates occur at the top of formations and vary in thickness from less than $1 \mathrm{~cm}$ to tens of centimeters. The base of these formations have graded bedding. These are interpreted as subaquatic slurry flows but may have a large amount of sediment from suspension flows associated for example with turbidity flows. Dropstones from clasts falling into soft preexisting sediments are also present in this class.

The fifth type is a chaotic melange of boulders of diamictite sandstone set in a variable matrix of massive to laminated diamictites. They are interpreted as forming by slumping of masses of glacial debris on the bottom of the outer shelf where slump planes pass through preglacial sediments.

The sixth type of till-tillite consists of conglomerate, sand, silt, and clay that may contain fragments of diamictite or other glacigenic sediments. These are interpreted to have formed in shelf environments from glacial meltwater where coarse sediments were deposited from a retreating ice front. 
The seventh type consists of mudstone and mixtures of mud and silt containing coarser clasts as large as boulders. These are interpreted to have been derived in basin or shelf environments from plumes of suspended material from meltwaters, heads of debris and other flows, sediments from winnowing by bottom currents, and clasts from floating ice.

Like Gravenor et al. (1984), Hambrey and Harland (1981) also define tillites as rocks of glacigenic origin, and they define diamictites as non-sorted, non-calcareous deposits composed of bimodal or polymodal clasts in a muddy matrix. They are essentially identical to those deposits known as mixtites, a term used to describe non-sorted or illsorted clastic sediments bearing megaclasts without regard to composition or origin.

\section{Are Some Ancient Tillites and Diamictites of Impact Origin?}

A glacial origin for tillites has been questioned by previous investigators. For example, Schermerhorn (1974, 1977) associated some tillite deposits with tectonic activity and hypothesized that tillites deposited at sea level during the hot Precambrian time were of non-glacial origin because they were interbedded with warm water sediments. In his opinion, only exceptionally large overspilling glaciers may have descended to sea level to deposit tills or aquatills. One deposit in Gorky, USSR, discussed by Chumakov (1981) was originally described by others as a tillite but has now been redescribed as a deposit of an impact crater! But this occurred only after extensive drilling revealed that an impact crater existed beneath the center of the deposit. Other tillites of impact origin might have been similarly mistaken as glacigenic. Tillites have been identified as glacial because they are characterized by dropstones, graded bedding, crude varving or laminations, and chaotic mixtures of rock clasts, some of which are striated, in fine-grained matrices. Striations are present on substrates beneath some deposits. But these textures also exist in impact deposits.

Class 1 and 2 tillites of Gravenor et al. (1984) resemble the Ries impact deposit. Both have very large assorted blocks of rock mixed chaotically into a fine-grained matrix. Textural similarity between Ries ejecta and glacial deposits is emphasized by the observation of Chao (1976) that before the existence of impacts craters was widely known, investigators had noticed striations on pebbles within the Ries ejecta when attempting to distinguish the deposit from a glacial moraine.
Laminations, dropstones, and graded basal beds of Gravenor's class 3 and 4 tillites, believed to have resulted from turbidity flows initiated by glaciers and the release of boulders from ice rafts, are similar to the laminations, dropstones, and graded basal beds produced by impact-generated turbidity flows and ejecta dropped in the ocean from ejecta curtains. The laminations, graded beds, and slump textures found in classes 3 and 4 till-tillites are the same textures as those found in the $\mathrm{K} / \mathrm{T}$ impact deposits at Brazos river by Bourgeois et al. (1988) and at other $\mathrm{K} / \mathrm{T}$ boundary locations discussed above (also predicted by our model for impact in water). Dropstones in class 4 tillites are the same as those in the Precambrian ejecta deposit described by Gostin et al. (1986). The slump, turbidity, and redistribution textures found in tillite classes 5-7 are those expected in our idealized sediment sections for water impact deposits of figure 7.

Hambrey and Harland (1981) identify tillite deposits based upon purportedly unique glacial features: abraded bedrock surfaces with striations, grooves, polished pavements, nailhead striations and chattermarks, stone-rich beds, dropstones in laminated sediments, finely grained stratification, striated pebbles and great thickness and extent of unsorted deposits with a wide range of grain sizes and association of tillites with resedimented material. They note that striated surfaces could be characteristic of mass flow processes other than glaciation but glacial striations tend to form in two or three intersecting sets which they believe are unique to the glacial process. Similarly, they point out that nailhead striations or chattermarks are unique to glaciation.

Chao (1976) reported that nailhead striations formed on clasts in deposits of the Ries crater. In a review of tillites and diamictites in South America and Africa described by Amos and Gamundi (1981) and Rocha-Campos and Dos Santos (1981) and others in Hambrey and Harland (1981), we find that the main criteria used to label a deposit a tillite rather than a diamictite, is the presence of dropstones, simple striations, boulder pavements, rythmites, and varve like sediment layers. As we have shown, thick, stone-rich beds, dropstones, laminations, rythmites and striations on underlying formations can be produced by crater ejecta deposition. While we know of no instances of chattermarks beneath known impact deposits we believe they could form in this environment (as could nailhead striations). In addition, our sample of deposits that have been identified as impact deposits is very limited and further samples may pro- 
duce deposits with chattermarks, especially if some of the deposits now described as tillites or diamictites are proven to be impact ejecta!

Similar processes acting during emplacement of impact and glacial deposits explain the similarity in textures of both types of material. Both impact cratering and ice erosion excavate a chaotic illsorted assemblage of debris. Both grounded glaciers and crater ejecta curtains erode substrates during deposit emplacement. The erosional interface is a mechanically coupled solid/solid interface, unlike the typical depositional environment for other fluid (loose) boundary interfaces. Both impact craters and glaciers transport exotic material great distances and mix and move exotic material and erosional debris along the ground and simultaneously scout and striate the substrate (and clasts) during deposit emplacement. Both glaciers and impact ejecta curtains drop debris in water and form graded beds and dropstones. Finally, both glaciers and impacts destabilize shelf slopes and produce turbidity sediment flows and structures.

The idea that such disparate processes as impact and glaciation might produce similar deposits is supported by the conclusions of Weller (1960). He notes that the origins of many of the ancient tillites are questionable because different processes could produce the textures observed in tillites; without corroborating geomorphic features, it is difficult to determine the origin of a till-like deposit based solely on textural information. However, other criteria can reveal the origin of such deposits. While no mathematical predictions of the thickness of glacial deposits that might be produced in a given span of time can be made, such predictions can be made for impact crater deposits.

The relative thickness distribution of impact deposits that we would expect to encounter in the past $2 \mathrm{~Gy}$ of the geologic record can be calculated from our impact model. The relative thickness distribution is the number of deposits produced of thickness $\geq t$ divided by the total number of deposits of all thicknesses. The number of impact deposits with thickness $\geq t$ expected in 2 Gy of Earth's geological record is proportional to the fractional area of Earth's surface covered by ejecta with thickness $\geq t$ in $2 \mathrm{~Gy}$. We have already derived the fraction of Earth's surface covered in 2 Gy by impact ejecta with thickness $\geq t$ (eq. 14). Therefore, the relative thickness distribution for impact deposits that should be encountered in the geologic record is given by the ratio of the fraction of Earth's surface covered by deposits $\geq t$ and the fraction of the surface covered by all deposits $\geq 100$ meters:
Fractional Area of Earth with Ejecta $\geq t$ Fractional Area of Earth with Ejecta $\geq 100 \mathrm{~m}$

$$
\begin{aligned}
&=\left\{\left[\frac{\alpha-2}{24} \frac{C\left(3+C^{2}\right)}{F t}\right]^{2 / \alpha} \frac{\alpha}{2+0.2 \alpha}\right. \\
&\left.\times\left(D_{\max }^{(2+0.2 \alpha) / \alpha}-D_{\min }^{(2+0.2 \alpha) / \alpha}\right)-5\left(D_{\max }^{0.2}-D_{\min }^{0.2}\right)\right\} / \\
& \\
&\left\{\left[\frac{\alpha-2}{2.4} \frac{C\left(3+C^{2}\right)}{F}\right]^{2 / \alpha} \frac{\alpha}{2+0.2 \alpha}\right. \\
&\left.\times\left(D_{\max }^{(2+0.2 \alpha) / \alpha}-D_{\min }^{(2+0.2 \alpha) / \alpha}\right)-5\left(D_{\max }^{0.2}-D_{\min }^{0.2}\right)\right\}
\end{aligned}
$$

This relative thickness distribution can be compared to that for tillites and diamictites produced over the same time span. From the worldwide compilation of the tillites and diamictites younger than $2 \mathrm{Ga}$ provided by Hambrey and Harland (1981), we measured the thickness of 174 deposits younger than $2 \mathrm{Ga}$ between $10 \mathrm{~m}$ and $3300 \mathrm{~m}$ thick. The number having an indicated thickness is plotted in figure 8 . The actual production of deposits must follow the dashed line. The lower frequencies for deposits $<100 \mathrm{~m}$ thick must result from erosion and lack of recording such very thin deposits. The maximum tillite/diamictite thicknesses we observed exceeded $3000 \mathrm{~m}$. These values agree remarkably well with the maximum thickness of deposits of impact craters approximating the largest produced in $2 \mathrm{Ga}$ (equation 8). We replot the data of figure 8 in figure 9 as the ratio of the number of deposits $\geq t$ to the total number of deposits $\geq 100 \mathrm{~m}$. This gives the relative thickness distribution of tillite/diamictite deposits younger than $2 \mathrm{Ga}$. Figure 9 compares the calculated relative thickness distributions for impact deposits using different values of $C$ in equation 16 with the

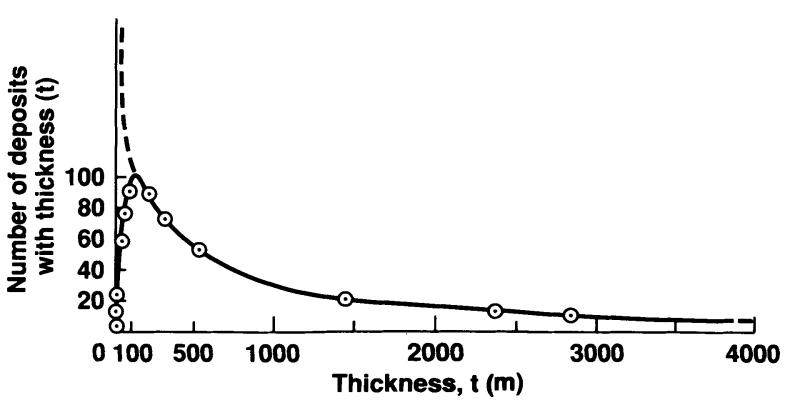

Figure 8. Number of tillite and diamictite deposits with indicated thickness as sampled from stratigraphic sections in Hambrey and Harland (1981). 


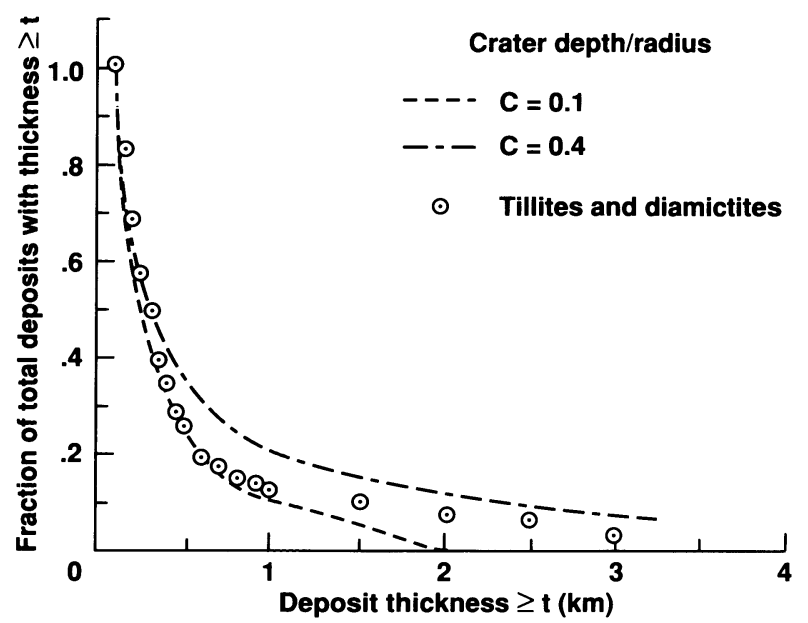

Figure 9. Comparison of the relative thickness distribution of tillites/diamictites with the relative thickness distributions of impact crater deposits from craters with depth/radius ratios $C=0.1-0.4$ formed during the last 2 Gy.

thickness distribution for tillites and diamictites. There is good agreement between the curve for tillites/diamictites and those for impact deposits of craters with $C=0.1$. We assume here that the curve for tillites/diamictites is reflective of the production curve. Deposition of most tillites/diamictites in marine environments may have favored preservation of deposits $\geq 100 \mathrm{~m}$.

The lithological similarity of impact and glacial deposits and similar deposit emplacement characteristics, along with our calculation of the range and form of the thickness distribution of tillites/ diamictites from our impact model, suggests that many tillites/diamictites could be impact deposits. But, are there any compelling geologic and climatologic reasons to seek an alternate to a glacial explanation for some of the ancient tillites? The concept of ancient glaciation has met with certain difficulties. The discovery of tillites of supposed glacial origin in tropical regions such as India was initially a puzzle until it was proposed that continental drift moved India to warmer regions after supposed glaciation within Gondwanaland while it was at high southern latitudes. However, Myerhoff and Teichert $(1971 a, 1971 b)$ argued that glacial tills could not have formed in the interior of Gondwanaland because a nearby ocean was required for a source of atmospheric water to form continental glaciers. In their view, abundant atmospheric water from distant oceans would not have been available on the interior of the vast supercontinent. They pointed out that until the advocates of conti- nental drift find another non-glacial explanation for tillites, the reality of the new tectonics (seafloor spreading and mobile plates) should be regarded as speculative. Since continental drift is now widely accepted, Myerhoff and Teichert's ideas regarding the absence of glaciation on the interior of Gondwanaland may merit further consideration within the context of an impact origin for some tillites.

There are additional difficulties with a glacial origin for all tillites. Temperature profiles presented in figure 70 of Salop (1983) indicate very high global temperatures at the time of tillite deposition. Salop notes that glaciation would have to have taken place during times when climate was very hot because tillites commonly have direct contact with hot-climate sediments. Moreover, glaciation must have taken place irrespective of geographic latitude. Such sudden and short periods of glaciation just before and immediately after very warm periods, and the lack of terrestrial mechanisms to explain this phenomenon, prompted Salop to suggest that catastrophic supernovae caused glaciation. Asteroid and comet impacts are also catastrophic extraterrestrial events that can explain tillites and diamictites. In addition, Albritton (1989) has pointed out that glaciation (inferred by tillites at the Ordivician-Silurian boundary) conflicts with a period of greenhouse activity inferred at this time from the supercycle concept for global temperatures (Fischer 1984).

An impact origin for some tillites could also explain the coincidence of major periods of biologic extinctions with periods of glaciation as inferred from tillite emplacement as noted in figures 70 and 71 of Salop (1983). Salop notes that glaciations could not be the cause of such biological crises and proposed supernovae outbursts to explain both biologic extinctions and glaciations. However, the hypothesis that dinosaurs may have become extinct as a result of impact (Alvarez et al. 1980) suggests that early extinctions, as well as the tillites/diamictites, may be explained by large impact events.

A glacial origin for some tillites can also be questioned because some of their characteristics are difficult to assign to a glacial origin. For example, Pleistocene glaciation was extensive, yet Pleistocene tills do not exceed $300 \mathrm{~m}$ thickness (Weller 1960). This is far less than the thickest tillite deposits of thousands of meters compiled by Hambrey and Harland (1981). We also note that glacial motion (and by inference, corresponding deposition) is divergent from an erosive center-not convergent. To obtain deposit thicknesses $\geq 3000 \mathrm{~m}$ 
implies erosion at a glacial center much in excess of $3000 \mathrm{~m}$. This has never been demonstrated.

Clear cut, sharply defined varves in known glacial deposits are mimicked in some tillites only by crude laminations. Tillites can contain individual rock clasts hundreds of meters in size. Glacial deposits of continental ice sheets do not contain such large blocks of rock because they are not powerful erosive agents. Advancing ice sheets simply collect the debris and deposit it after a short distance (Whillans 1978). Continental ice sheets only remove irregularities in the pre-existing surface and, in general, glide along the surface without fracturing substantial amounts of bedrock. Impact cratering crushes the rock within the crater before ejecting it. Maximum block size is limited only by the scale of rock jointing in the formations. Blocks of $200 \mathrm{~m}$ were produced during formation of the
Ries impact crater; even larger ones are observed near the rims of lunar craters (Moore 1972).

Despite the extensive amount of excellent field work that has produced observations compatible with ancient glaciation, we have considered the possibility of impact origin for some of the tillites and diamictites because of our calculations and observations, and because of the geological and geophysical implication of our hypothesis.

\section{Impacts and the Breakup of Gondwanaland}

The locations of post-Carboniferous tillites and diamictites between 280/345 $\mathrm{Ma}$ and $65 \mathrm{Ma}$ are redrawn from Hambrey and Harland (1981) in figure 10. The uncertainty of the lower bound in age of the tillites/diamictites is the duration of one geologic period. Many of the tillites shown are those for which there has been the most extensive field

Figure 10. Comparison of the locations of flood basalts and tillites/diamictites.
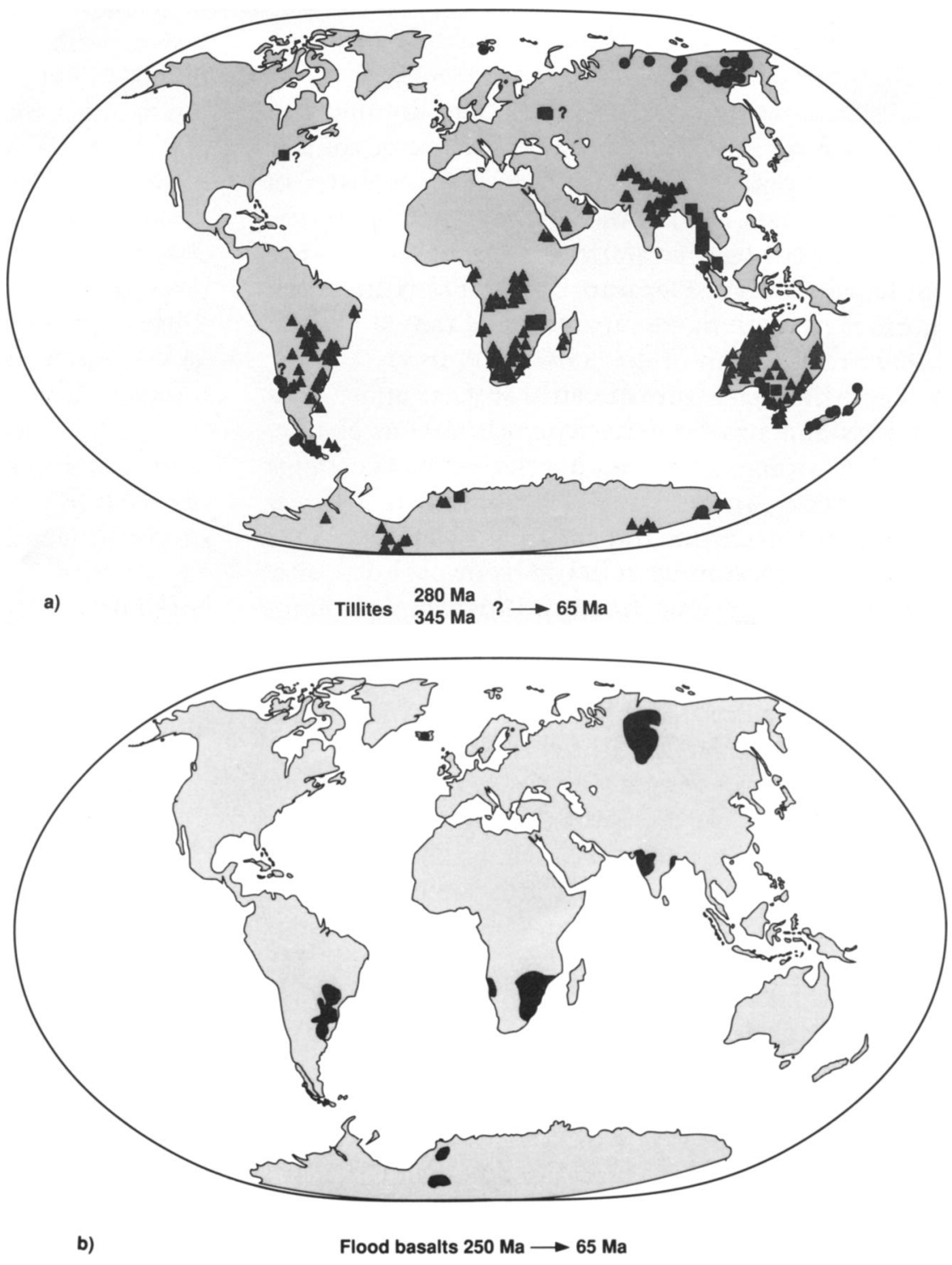
work suggesting a glacial origin. However, our results compel consideration of the consequences if some of these deposits are of impact origin. The locations of post-Carboniferous flood basalts are also shown in figure 10 . These include three of the four major continental flood basalt plateaus as described in Basaltic Volcanism Study Project (1981). They are the Parana Basin (119-149 Ma), the Karoo Province (166-206 Ma), and the Siberian Platform (216-248 Ma). The Lake Superior Basin basalts (1100-1120 Ma) are not shown. The tillite/basalt geographical and temporal relationships shown in figure 10 suggest the possibility that the flood basalts and some of the tillites are related in origin. During Carboniferous and Permian time, extensive tillite/diamictite deposits were formed on what are now South America, South Africa, Antarctica, India, and Australia. This was followed by the most extensive eruption of flood basalts in geologic history, and then by breakup of the supercontinent. Flood basalts postdate tillites/diamictites and occur in the same regions of the continents.

Richards et al. (1989) believe that the heads of mantle plumes initiated terrestrial flood basalt volcanism. White and McKenzie (1989) suggest that basalt eruptions occur at continental margins as a previously thinned region of crust is rifted as it drifts over a mantle plume. Impacts may also have fractured and thinned the crust and triggered flood basalt eruptions. Green (1972) proposed that the lower portions of the volcanic sequences of some Archean greenstone belts represent $60-80 \%$ melting of mantle sources as a result of catastrophic major impacts on the surface of primitive Earth; a similar process to that for lunar maria. Melting results from pressure relief as impacts excavated and uplifted material from the mantle. Wilhelms 1987 proposed that flood basalts on the lunar maria may have been erupted from magma chambers after impacts fractured the lunar crust and provided escape conduits. Frey (1980) and Grieve (1980) both suggested that formation of impact basins larger than $200-1000 \mathrm{~km}$ that formed before 3.9 $\mathrm{Ga}$ played an important role in the formation of the proto-crust of the Earth. These impacts would have generated extensive basaltic volcanism. Grieve proposed that impacts initiated formation of mantle plumes. Alt et al. (1988) suggested that terrestrial flood basalts might also have formed as a result of deep excavation following formation of impact craters of the order of $100 \mathrm{~km}$ after the Cretaceous period. Thus, eruptions of flood basalts in figure 10 may also have been triggered by impacts that emplaced some of the tillites and diamictites.
Alt et al. (1988) specified terrestrial lava plateaus as the sites of impact craters $>100 \mathrm{~km}$ that collapsed and were buried by the basalt flows whose eruptions they triggered. They suggested that crater formation started hotspots by initiating pressure-relief melting and persistent low pressure cells that produced mantle plumes and associated flood basalts. They concluded that large impact craters also produced continental rifting and oceanic spreading ridges. They identified the Columbia Lava Plateau with its associated continental rifting in the northern Basin and Range and Yellowstone hotspot track along the Snake River Plain, and the Deccan Plateau with the ChagosLaccadive hotspot track and the Carlsberg oceanic ridge. The authors observed that these features form abruptly within plates without apparent tectonic cause. Frey (1980) also proposed that impact bombardment before $3.9 \mathrm{Ga}$ influenced initiation of plate tectonics when craters $1000 \mathrm{~km}$ and larger fractured the lithosphere and facilitated formation of microplates. Thus, the distribution of tillites and flood basalts at the interior of Gondwanaland, the association of impacts and flood basalt volcanism (as referenced above) and the association of crustal rifting with impact cratering (Alt et al. and Frey's suggestion), leads us to explore the possibility that continental crustal fracturing associated with impact cratering may have played a key role in initiating the breakup of Gondwanaland.

Continental crustal plates are rigid and of high strength; some mechanism is required to initiate continental breakup. The most recent view is that high-temperature mantle plumes were either passively or actively involved. The passive model has been developed and reviewed by White and McKenzie (1989). They argue that magmatically active continental margins, characterized by eruption of flood basalts onto the adjacent continents, are explained by crustal rifting above a thermal anomaly in the underlying mantle when a previously thinned and stretched region of the crust drifts over a mantle plume. They suggest that mantle plumes alone can sometimes rift the previously thinned crust and initiate continental breakup. The mantle diapirs actually initiate crustal fracturing immediately above the plume in the active model of crustal rifting. For example, Bahat and Rabinovitch (1983) proposed that crustal fracture initiation as well as subsequent propagation and bifurcation along the Dead Sea rift are best explained by the "active" mechanism. However, Hill (1991) argues that mantle plumes alone would not have been able to provide sufficient stress to initiate breakup. He believes that plumes lead only to 
local reorganization of plate-scale motions, only enhance propagation of an existing ridge system, or provide only sufficient extra force to drive a weak plate-scale system from slow spreading through to continental rifting.

The passive and active models for rifting and basaltic eruptions apparently require thermal instabilities at the core-mantle boundary to generate plumes that reach all the way to the surface. However, the concept of mantle plumes actually originated from the observation that progressive basaltic eruption from one spot in the upper mantle produced chains of basaltic islands as the crust drifted over it. Pressure relief that produces basaltic eruptions from an upper mantle site may result from impacts that easily penetrate the thin oceanic crust. We suggest that larger craters forming on the continents could also have initiated rifting as well as basalt eruptions.

Impact craters are capable of removing entire sections of the Earth's crust and can fracture the surrounding crust and subjacent upper mantle. Jones (1987) combined theoretical calculations with knowledge of the dynamic tensile behavior of rock and concluded that the propagating shock wave associated with formation of impact craters larger than $24 \mathrm{~km}$ would fracture the crust down to the Moho. He also concluded that such faults might be observable. Our calculations indicate that there would have been thousands of craters of this size formed during the last $2 \mathrm{~Gy}$. In particular, paleomaps of the continents show that a supercontinent, in one configuration or another, existed as long ago as 1.2 Ga (Morel and Irving 1978).

We suggest that prolonged impact cratering preceding breakup of Gondwanaland (indicated by Permo-Carboniferous tillites in South Africa, South America, India, and Antarctica) could have extensively fractured the lithosphere and would have facilitated the final continental fragmentation. Note that equation (1) shows that roughly 12 impact craters $>100 \mathrm{~km}$ would have been formed on the continents in the billion years before the breakup; some of these might have initiated upper mantle plumes. The crustal fracturing from these impacts, as well as that from many more smaller ones, would have produced an extensive network of fracture weaknesses permeating the lithosphere. These fractures would have propagated vertically and radially as the lithosphere was stressed by doming above magma plumes. Tillites could represent deposits of the largest of the impact craters formed during the last few hundred million years before continental breakup.

Consider one possible relation between a hot spot, tillite/diamictite deposit, and flood basalt that may have been involved in Gondwanaland breakup. Richards et al. (1989) consider that the Karoo phase of basaltic volcanism in South Africa in the Early Jurassic period is associated with the Marion-Prince Edward hot spot. This hot spot may have been the site of an impact in Permian time when it produced some of the tillites (including Karoo tillites) now found displaced from the flood basalts by relatively small distances equal to the drift of Gondwanaland between Permian and Jurassic time. Fractures formed in the upper mantle by that impact could have triggered eruption of the Karoo flood basalts in the Jurassic. Fractures formed in the crust near the original impact site could also have assisted in continental breakup as the crust was subjected to lateral tensile stresses above the upper mantle plume. Relatively little delay between impacts and ensuing flood basalt eruptions results in a good geographic correlation between tillites/diamictites and flood basalts. In other cases, if there was a long delay between impacts and eruptions, the stationary mantle hot spot would erupt basalts geographically displaced from the tillite/diamictite deposits being rafted on the moving continental crust. The longer the delay, the greater the displacement. This could explain the lack of flood basalts for some regions containing tillites or diamictites in figure 10.

Evidence of impact deformation associated with Gondwanaland breakup could be the South African Cape fold belt, adjacent to the Karoo basin, together with the major rifting deformation affecting central Africa during the Late Permian. Daly et al. (1991) noted that the rifting force is uncertain but could be a collision of Gondwanaland and another continent. However, it may be difficult to produce such major deformations at the interiors of colliding supercontinents. We suggest that the Cape fold belt and associated basins be investigated as possible remnants of large impact basins left after continental breakup.

It is noteworthy that King and Zietz (1971) also have described midcontinent rifting from Minnesota and Wisconsin through Iowa and Nebraska associated with the belt of Precambrian Keweenawan flood basalts. Again, the tillites predate the basalts. However, in this North American example, the Huronian tillites predate the Keweenawan basalt by hundreds of millions of years. Perhaps the very stable craton in this area prevented continental breakup and delayed and minimized flood basalt eruptions more than usual.

\section{Discussion}

We have considered the possibility of an impact origin for tillites and diamictites because textures 
of tillite/diamictite and impact deposits are similar, and because tillite/diamictite and impact deposits have similar thickness distributions. On the other hand, all of the existing field work implies a glacial origin for tillites. Our model suggests that impact deposits in excess of $3 \mathrm{~km}$ thickness should have been produced during the past $2 \mathrm{~Gy}$, and we observe tillites/diamictites up to and including this thickness. However, none of the tillite or diamictite deposits of this thickness have yet been attributed to impact. Even though there is no way of knowing if glacial deposits 10 times thicker than Pleistocene deposits and with the same appearance as impact deposits could have been produced in ancient times, and even though there is no way of predicting the total extent of glacial deposits in the past, it is widely assumed that even the thickest of the tillites are of glacial origin. If none of the tillite/diamictite deposits are of impact origin, then we are left with a disturbing problem: How do ancient glacial deposits become preserved, while expected impact crater deposits equal to the thickest of the ancient tillites (and with the same appearance as tillites) become removed without a trace? This problem is compounded by the fact that most glacial deposits should have formed on land whereas most impact deposits should have formed in water and should therefore have had a greater chance for preservation.

If some of the tillites/diamictites are of impact origin, there would have been fewer early periods of glaciation, the puzzle of association of extinctions with glaciations would be solved, and there would be fewer difficulties associated with sudden glaciation during the time of globally hot climates. It may be possible, after considerable work, finally to prove the origin of each tillite/diamictite deposit. Until all tillites/diamictites are examined for shock-damaged materials, impact spherules, iridium concentrations, and other impact signatures, both impact and glacial origins remain viable explanations for any particular deposit. As Gostin et al. (1986) have noted, impact dropstones in marine deposits of Precambrian age were identified on the basis of shock lamellae. Detailed searches of the ancient tillites/diamictites should be undertaken. Horz et al. (1983) showed that such shocked samples occur in igneous and metamorphic rock clast making up $<1 \%$ of the Ries ejecta. However, shock lamellae in some ancient tillites could have been annealed by diagenesis and metamorphism.

The idea that complex and thick successions of tillites could be formed in a matter of hours to years seems absurd on first reflection. However, catastrophes are as much a part of the natural order as are events associated with quiescent periods. The solar system bears witness to the catastrophic formation of massive planetary deposits of crushed impact regolith, volcanic constructs, and gravityinduced deposition by slumping, avalanching, flooding, and violent turbidity currents. If many of the tillites are indeed impact deposits, impacting asteroids and comets may have been much more important to geologic processes than is presently understood.

While it is currently assumed that flood basalt eruptions and rifting were produced by mantle plumes that formed by instabilities associated with heat released non-uniformly from the Earth's core, we support earlier views that impacts may have initiated continental rifting and basaltic volcanism. Our results suggest that impacts may have been constantly at work in shaping the continents; they could have determined the way in which continents broke up and then drifted. Impact craters caused fractures, removed crustal material, reduced overburden pressure, initiated basaltic volcanism, and enhanced continental rifting which permitted the continents to separate. Impacts of asteroids and comets may have initiated breakup of Gondwanaland and other continental land masses.

\section{ACKNOWLEDGMENT}

The authors wish to thank D. Alt for his helpful review of the manuscript.

\section{REFERENCES CITED}

Ahrens, T. J., and O'Keefe, J. D., 1983, Impact of an asteroid or comet in the ocean and extinction of terrestrial life, in Proc. of the 13th Lunar and Planetary Science Conf. Part 2: Jour. Geophys. Res., v. 88, Suppl., p. A799-A806.

Albritton, C. C., Jr., 1989, Catastrophic episodes in Earth history: New York, Chapman and Hall, 221 p.

Alt, D.; Sears, J. M.; and Hyndman, D. W., 1988, Terres- trial maria: the origins of large basalt plateaus, hotspot tracks, and spreading ridges: Jour. Geology, v. 96, p. 647-662.

Alvarez, L. W.; Alvarez, W.; Asaro, F.; and Michel, H. V., 1980, Extraterrestrial cause for the CretaceousTertiary extinction: Science, v. 208, p. 1095-1106.

Alvarez, W.; Smit, J.; Asaro, F.; Lowrie, W.; Kastner, M.; and Margolis, S. V., 1991, Proximal impact deposits 
at the Cretaceous-Tertiary boundary in the Gulf of Mexico: reinterpreting DSDP Sites 536 and 540: Geol. Soc. America Abs. with Prog., v. 877, p. A420.

Amos, A. J., and Gamundi, O. L., 1981, Late Paleozoic S. Grande Formation of eastern Argentina, in Hambrey, M., and Harland, W. B., eds., Earth's prePleistocene Glacial Record: London, Cambridge University Press, p. 872.

Bahat, D., and Rabinovitch, A., 1983, The initiation of the dead sea rift: Jour. Geology, v. 91, p. 317-332.

Basaltic Volcanism Study Project, 1981, Basaltic Volcanism on the Terrestrial Planets: New York, Pergamon, $1286 \mathrm{p}$.

Bourgeois, J.; Hansen, T. A.; Wiberg, P. L.; and Kauffman, E. G., 1988, A tsunami deposit at the Cretaceous-Tertiary boundary in Texas: Science v. 241, p. 567-570.

Chamberlin, T. C., 1920, Diastrophism and the formative processes XIII. The bearings of the size and rate of infall of planetesimals on the molten or solid state of the Earth: Jour. Geology, v. 28, p. 665-701.

Chao, E. C. T., 1976, Mineral-produced high-pressure striae and clay polish: key evidence for nonballistic transport of ejecta from Ries Crater: Science, v. 194, p. 615-618.

Chumakov, N. M., 1981, Mesozoic tilloids of the middle Volga, USSR, in Hambrey, M., and Harland, W. B., eds., Earth's pre-Pleistocene Glacial Record: London, Cambridge University Press, p. 570.

Daly, M. C.; Lawrence, S.; Kimun'a, R.; and Binga, M., 1991, Late Paleozoic deformation in Central Africa: a result of distant collision?: Nature, v. 350, p. 605-607.

Engel, O. G., 1961, Collisions of liquid drops with liquids: Nat. Bur. Standards Tech. Note 89, 30 p.

Florentin, J.; Maurrasse, M. R.; and Gautam, S., 1991, Impacts, tsunamis, and the Haitian CretaceousTertiary boundary layer: Science, v. 252, p. 16901693.

Fischer, A. G., 1984, The two Phanerozoic supercycles, in Berggren, W. A., and van Couvering, J. A., eds., Catastrophes and Earth History: Princeton, NJ, Princeton University Press, p. 129-150.

Frey, H., 1980, Crustal evolution of the early Earth: the role of major impacts: Precamb. Res., v. 10, p. $195-216$.

Gault, D. E., and Sonnett, C. P., 1982, Laboratory simulation of pelagic asteroidal impact: atmospheric injection, benthic topography, and the surface wave radiation field, in Silver, L. T., and Schulz, P. H., eds., Geol. Soc. America Spec. Paper 190, p. 69-92.

Gostin, V. A.; Haines, P. W.; Jenkins, R. J. F.; Compston, W.; and Williams, I. S., 1986, Impact ejecta horizon within late Precambrian shales, Adelaide Geosyncline, south Australia: Science, v. 233, p. 133-252.

Gravenor, C. P., and Monteiro, R. L. B. P., 1983, Ice-trust features and a possible intertillite pavement in the Proterozoic Macaubas group, Jequitai area, Minas Gerais, Brazil: Jour. Geology, v. 91, p. 113-116.

- ; Von Brunn, V.; and Dreimanis, A., 1984, Nature and classification of waterlain glacigenic sediments, exemplified by Pleistocene, late Paleozoic and late Precambrian deposits: Earth Sci. Rev., v. 20, p. 105166.

Green, D. H., 1972, Archean greenstone belts may include terrestial equivalents of lunar maria?: Earth Planet. Sci. Lett., v. 15, p. 263-270.

Grieve, R. A. F., and Dence, M. R., 1979, The terrestrial cratering record, II. The crater production rate: Icarus, v. 38 , p. $230-242$.

- 1980, Impact bombardment and its role in protocontinental growth on the early Earth: Precamb. Res., v. 10, p. 217-247.

Hambrey, M. J., and Harland, W. B. (eds.), 1981, Earth's pre-Pleistocene Glacial Record: London, Cambridge University Press, 1004 p.

Hartmann, W. K., and Davis, D. R., 1975, Satellite-sized planetesimals and lunar origin: Icarus, v. 24, p. 504-515.

1980, Dropping stones in magma oceans, in Papike, J. J., and Merrill, R. B., eds., Effects of early lunar Cratering: Proc. Conf. Lunar Highlands Crust, p. 155-171.

Head, J. W.; Settle, M.; and Stein, R. S.; 1975, Volume of material ejected from major lunar basins and implications for the depth of excavation of lunar samples: Proc. 6th Lunar Sci. Conf., p. 2805-2829.

Hill, R. I., 1991, Starting plumes and continental breakup: Earth Planet. Sci. Lett., v. 104, p. 398-416.

Hildebrand, A. R., 1992, K/T boundary ejecta distribution predicts size and location of Chicxulub Crater; 23rd Lunar Planet. Sci. Conf. (Abs.), p. 537-538.

Horz, F.; Gall, H.; Huttner, R.; and Oberbeck, V. R., 1977, Shallow drilling in the "Bunte Breccia" impact deposits, Ries Crater, Germany, in Roddy, D. J.; Pepin, R. O.; and Merrill, R. B., eds., Impact and Explosion Cratering: New York, Pergamon, p. 425448.

; Ostertag, G. R.; and Rainey, D. A., 1983, Bunte breccia of the Ries: continuous deposits of large impact craters: Rev. Geophys. Space Phys., v. 21, p. 1667-1725.

Jones, A. G., 1987, Are impact-generated lower-crustal faults observable?: Geol. Survey Canada Pub. 14386, $000 \mathrm{p}$.

King, R., and Zietz, I., 1971, Aeromagnetic study of the midcontinent gravity high of central United States: Geol. Soc. America Bull., v. 82, p. 2187-2208.

Maher, K., and Stevenson, D. J., 1988, Impact frustration of the origin of life: Nature, v. 331, p. 612-614.

McGetchin, T. R.; Settle, M.; and Head, J. W., 1973, Radial thickness variation in impact crater ejecta: implications for lunar basin deposits: Earth Planet. Sci. Lett., v. 20, p. 226-236.

McKinnon, W. B., 1982, Impact into the Earth's ocean floor: preliminary experiments, a planetary model, and possibilities for detection, in Silver L. T., and Schultz, P. H., eds., Geol. Soc. America Spec. Paper 190, p. 129-142.

Melosh, H. J., 1982, A schematic model of crater modification by gravity: Jour. Geophs. Res., v. 87, p. $371-380$. 
Meyerhoff, A. A., and Teichert, C., 1971a, Continental drift, III: late Paleozoic glacial centers and DevonianEocene coal distribution: Jour. Geology, v. 79, p. 285-321.

, and $\longrightarrow, 1971 b$, Discussing paper by D. J. Gough, "Did an ice cap break Gondwanaland?: Jour. Geophys. Res., v. 76, p. 4038-4044.

Moore, H. J., 1972, Ranger and other impact craters photographed by Apollo 16, in Apollo 16 Prelim. Sci. Rep., NASA SP-315, p. 29-45-29-51.

Morel, P., and Irving, E., 1978, Tentative paleocontinental maps for the early Phanerozoic and Proterozoic: Jour. Geology, v. 86, p. 535-565.

Oberbeck, V. R., 1975, The role of ballistic erosion and sedimentation in lunar stratigraphy: Rev. Geophys. Space Phys., v. 13, p. 337-362.

$\longrightarrow$, and Fogleman, G., 1989, Impact and the origin of life: Nature, v. 339, p. 434.

$\longrightarrow$, and -1990 , Impact constraints on the origin of life: Origin and Evolution of the Biosphere, v. 20, p. 181-195.

; Horz, F.; Morrison, R.; Quaide, W. L.; and Gault, D. E., 1975, On the origin of the lunar smooth plains: The Moon, v. 12, p. 19-54.

Orphal, D. I., 1979, Depth, thickness, and volume of the breccia lens for simple explosion and impact craters: Tenth Lunar Planet. Sci. Conf., p. 949-951.

Poag, C.; Wylie, C.; et al., 1991, An upper Eocene impact-wave (?) deposit beneath Chesapeake bay: Geol. Soc. America Abs. with Prog., p. A460.

Pohl, J.; Stoffler, D.; Gall, H.; and Ernston, K., 1977, The Ries impact crater, in Roddy, D. J.; Pepin, R. O.; and Merrill, R. B., eds., Impact and Explosion Cratering: New York, Pergamon, p. 343-404.

Richards, M. A.; Duncan, R. A.; and Courtillot, V. E., 1989, Flood basalts and hot spot tracks: plume heads and tails: Science, v. 246, p. 103-107.

Rocha-Campos, A. C., and Dos Santos, P. R., 1981, The Itarare Subgroup, Aquidauana Group and San Gregorio Formation, Parana Basin, southeastern South America, in Hambrey, M., and Harland, W. B., eds.: Earth's pre-Pleistocene Glacial Record: London, Cambridge University Press, p. 842-852.

Safronov, V. S., 1972, Evolution of the protoplanetary cloud and formation of the Earth and the planets: Ixdatel'stvo "Nauka," Moskva, 1969, TT 71-50049, NASA TT F-677 (translated from Russian, Israel Prog. Sci. Translations, avail. from U.S. Dept. Commerce, Springfield, Va 22151) 206 p.

, and Zvjagina, E. V., 1969, Relative sizes of the largest bodies during the accumulation of planets: Icarus, v. 10, p. 109.
Salop, L. J., 1983, Geologic evolution of the Earth during the Precambrian: New York, Springer-Verlag, 459 p.

Schermerhorn, L. J. G., 1974, Later Precambrian mixtites: glacial and or nonglacial?: Am. Jour. Sci, v. 274, p. $673-824$.

, 1977, Late Precambrian dolomites, Vendian glaciation, and synchroneity of Vendian glaciations: a discussion: Jour. Geology, v. 85, p. 247-250.

Seebaugh, W. R., 1977, A dynamic crater ejecta model in Roddy, D. J.; Pepin, R. O.; and Merrill, R. B., eds., Impact and Explosion Cratering: New York, Pergamon, p. 1043-1056.

Shoemaker, E. M., 1983, Asteroid and comet bombardment of the Earth: Ann. Rev. Earth Planet. Sci., v. 11, p. 461-494.

Short, N., and Forman, M., 1972, Thickness of impact crater ejecta on the lunar surface: Mod. Geol., v. 32, p. 69.

Smit, J., and Romein, A. J. T., 1985, A sequence of events across the Cretaceous-Tertiary boundary: Earth Planet. Sci. Lett., v. 74, p. 155-170.

Snedecor, G. W., and Cochran, W. G., 1976, Statistical Methods: Ames Iowa, Iowa State University Press, $593 \mathrm{p}$.

Swisher, C. C.; Grajales-Nishimura, J. M.; et al., 1992, Coeval ${ }^{40} \mathrm{Ar} /{ }^{39} \mathrm{Ar}$ Ages of 65.0 million years ago from Chicxulub Crater melt rock and Cretaceous-Tertiary boundary tektites: Science, v. 257, p. 954-958.

Vickery, A. M.; Kring, D. A.; and Melosh, H. J., 1992, Ejecta associated with large terrestrial impacts: implications for the Chicxulub impact and $\mathrm{K} / \mathrm{T}$ boundary stratigraphy: 23rd Lunar Planet. Sci. Conf., p. 14731474.

Weller, J. M., 1960, Stratigraphic Principles and Practice: New York, Harper, 725 p.

Whillans, I. M., 1978, Erosion by continental ice sheets: Jour. Geology, v. 86, p. 516-524.

White R., and McKenzie, D., 1989, Magmatism at rift zones: the generation of volcanic continental margins and flood basalts: Jour. Geophys. Res., v. 94 p. 7685-7729.

Wilhelms, D. E., 1987, The geologic history of the moon: U.S. Geol. Survey Prof. Paper 1348, 302 p.

-, and Squyres S. W., 1984, The Martian hemispheric dichotomy may be due to a giant impact: $\mathrm{Na}$ ture, v. 309, p. 138-140.

Williams, G. E., 1986, The Acraman impact structure: source of ejecta in late Precambrian shales, South Australia: Science, v. 233, p. 200-203. 